\title{
DAMPAK PENYALURAN DANA ZISWAF (ZAKAT, INFAQ, SEDEKAH DAN WAKAF) PADA PROGRAM PENDIDIKAN STID MOHAMMAD NATSIR BERDASARKAN SOCIAL RETURN ON INVESTMENT
}

\begin{tabular}{|c|c|c|c|}
\hline \multicolumn{4}{|c|}{ P-ISSN: 2085-4536 | E-ISSN: 2721-7183 } \\
\hline \multicolumn{4}{|c|}{ Link: https://jurnal-stidnatsir.ac.id/index.php/binaummat/article/view/38 } \\
\hline \multicolumn{4}{|c|}{ DOI : $\underline{\text { https://doi.org/10.38214/jurnalbinaummatstidnatsir.v2i01.38 }}$} \\
\hline Dikirim: 25-03-2019 & Direviev & 2019 & Diterbitkan: 17-04-2019 \\
\hline \multicolumn{2}{|c|}{$\begin{array}{c}\text { UJANG HABIBI } \\
\text { STID Mohammad Natsir, Indonesia } \\
\text { habibi@stidnatsir.ac.id }\end{array}$} & \multicolumn{2}{|c|}{$\begin{array}{l}\text { NAQIYYA SYAMILAH } \\
\text { STEI SEBI, Indonesia } \\
\text { giyya.hafidzah99@gmail.com }\end{array}$} \\
\hline
\end{tabular}

\begin{abstract}
ABSTRAK
Tujuan Penelitian: Penelitian ini bertujuan untuk menghitung dampak yang dihasilkan oleh STID Mohammad Natsir dengan menggunakan metode Social Return on Investment (SROI). Metode Penelitian: Kuantitatif. Hasil Penelitian: Hasil akhir dari rasio SROI penelitian ini menunjukkan 28:1. Hal ini berarti untuk setiap Rp.1,- yang diinvestasikan, akan menghasilkan nilai sosial sebesar Rp.28,sebagai manfaat yang didapatkan oleh mahasiwa, alumni dan masyarakat. Hal ini menunjukkan bahwa STID Mohammad Natsir berhasil menciptakan dampak sosial yang membawa manfaat bagi mahasiwa, alumni dan masyarakat sekitar.
\end{abstract}

Kata Kunci: Pendidikan, ZISWAF,Dampak Sosial, SROI

\section{PENDAHULUAN}

Kemiskinan hingga kini masih menjadi masalah hampir seluruh negera, termasuk Indonesia. Walaupun secara statistik tahun 2018 Badan Pusat Statistik (BPS) mengungkapkan tingkat kemiskinan indonesia pada September 2018 tercatat menurun menjadi 25, 67 juta orang atau setara dengan 9, 66 persen dari total penduduk Indonesia.

Kemiskinan dan kehidupan di bawah garis kemiskinan merupakan sesuatu yang masih begitu banyak terjadi di sekitar kita. Yang satu berhasil

1 | Jurnal Bina Ummat | Vol.2 | No.1| 2019 
mengatasi kemiskinan, tetapi muncul lagi penduduk miskin yang baru dengan sebab-sebab tertentu. ${ }^{1}$ (Andi, 2013).

Sistem ekonomi Islam sangat menekankan upaya memberantas kemiskinan di tengah masyarakat, baik kemiskinan struktural maupun kultural. Kemiskinan struktural terjadi karena adanya ketimpangan dalam distribusi kekayaan akibat kesalahan dalam pemilihan sistem ekonomi dan kekeliruan dalam kebijakan negara. Kemiskinan kultural merupakan kemiskinan yang timbulolehfaktor-faktor individu seperti adanya sifat malas, kekurangmampuan dalam bekerja baik karena alasan fisik maupun non-fisik, kesalahan dalam memaknai rezeki atau karena adanya "budaya" miskin (Ismail, 2011).

Karena itu kepedulian kita terhadap upaya mengatasi kemiskinan merupakan sesuatu yang sangat penting. Islam merupakan agama yang amat menekankan kepada kita untuk bisa mengatasi kemiskinan, bahkan ada banyak petunjuknya di dalam Qur'an dan hadits-hadits. Bahkan, para ulama terus mencurahkan kemampuan berfikir untuk menggali ajaran islam dalam konteks mengatasi kemiskinan, sementara kaum muslimin juga terus berusaha dari tahun ke tahun dengan usaha yang maksimal guna mengatasi kemiskinan (Andi, 2013).

Saat ini kondisi muslim di pelosok nusantara terdapat banyak keluarga miskin di pedalaman nusantara. Masyarakat pedalaman terdiskriminasi dan terabaikan. Mereka hidup terbelakang dalam segala hal. Pendidikan terbelakang, fasilitas publik terbatas, layanan kesehatan langka, rumah ala kadarnya, makanan seadanya, kekeringan spiritual, dan sejumlah keterbelakangan lainya.

Kondisi yang serba kekurangan ini yang pada akhirnya terjadilah agenda-agenda pemurtadan karena tidak ada yang membina dan membentengi aqidah masyarakat pedalaman. Sekolah-sekolah dan institusi non muslim banyak yang memanfaatkan dan memberikan Pendidikan, bantuan sosial dan kesehatan gratis dengan agenda pemurtadan

Islam bukanlah agama yang tidak mampu mengatasi permasalahan umatnya, tetapi agama islam memberi solusi positif dalam menyelesaikan masalah tersebut dengan adanya perintah zakat. Islam dibangun atas atas lima dasar, yaitu syahadat, shalat, zakat, puasa dan haji. Diantara lima dasar 
tersebut adalah zakat yang menjadi tiang utama rukun islam ketiga, yang mempunyai dwi fungsi yaitu fungsi ritual (melakasnakan perintah Allah) yang harus dilaksanakan bagi tiap-tiap individu muslim yang telah memenuhi persyaratan wajib zakat; nisab dan haul dan juga melahirkan keshalehan social yaitu dapat mengurangi permasalah perekonomian juga kesejahteraan umat.

Indonesia merupakan salah satu negara dengan mayoritas penduduk muslim terbesar yaitu sejumlah 216,66 juta penduduk atau dengan persentase muslim sebesar 85 persen dari total populasi (IDEAS, n.d.). Fakta ini menyiratkan bahwa zakat memiliki potensi besar dan dapat berkontribusi dalam mengurangi kemiskinan (Badan Amil Zakat Nasional, 2017)

Dalam survei yang dilakukan oleh Ketua Badan Amil Zakat Nasional (Baznas) Bambang Sudibyo, mengatakan setiap tahunnya pengumpulan zakat terus mengalami peningkataan. Pada 2010, zakat yang diperoleh sekitar Rp 217 triliun dan terus mengalami peningkatan di 2016 yang menyentuh angka Rp 286 triliun (Assa'diyah \& Pramono, 2019).

Saat ini masih jarang penelitian yang membahas dampak dari pengelolaan zakat baik bagi penerima manfaat maupun pemangku kepentingan lain yang ikut berkontribusi dalam Organisasi Pengelola Zakat (OPZ). Salah satu metode analisis yang dapat digunakan untuk meneliti program sosial seperti pengelolaan zakat ini adalah Social Return on Invetstment (SROI).

Menurut (Nicholls, et.al. 2012:8) SROI merupakan suatu kerangka untuk mengukur dan akuntansi untuk suatu konsep nilai yang lebih luas, berusaha untuk mengurangi ketimpangan, degredasi lingkungan dan meningkatkan kesejahteraan dengan memasukkan nilai sosial, lingkungan, biaya ekonomi dan manfaat. SROI digunakan sebagai alat untuk perencanaan strategis dan peningkatan untuk mengkomunikasikan dampak dan investasi. SROI dapat membantu memfasilitasi diskusi strategis dan membantu memahami dan memaksimalkan nilai sosial yang dihasilkan dari kegiatan, membantu dalam membuat prioritas sumber daya yang tepat dalam mengelola hasil yang tak terduga, baik positif maupun negatif, memperlihatkan pentingnya bekerja dengan organisasi dan orang-orang yang berkontribusi dalam menciptakan perubahan, membantu untuk 
memaksimalkan nilai sosial dengan mengidentifikasi keselarasan antara apa yang ingin dicapai oleh organisasi dengan apa yang ingin dicapai para pemangku kepentingan, membuat dialog formal dengan para pemangku kepentingan yang memungkinkan mereka untuk lebih terlibat dan dihargai perannya dalam proses perubahan yang hendak dicapai.

Maka, salah satu program unggulan LAZNAS Dewan Dakwah yakni beasiswa kader da'i intelektual. Program ini adalah wujud terhadap peningkatan intelektual para da'i serta bentuk perhatian akan kesinambungan dakwah di masa mendatang. Dengan menyiapkan kader penerus, yang diharapkan seruan dakwah dapat terus berkumandang dan tumbuh di pelosok nusantara. Beasiswa ini diberikan kepada mahasiswa dari berbagai daerah untuk mendapatkan kesempatan kuliah S1 di Sekolah Tinggi Ilmu Dakwah Mohammad Natsir (STID Moh. Natsir). Setelah menyelesaikan pendidikan formal di bangku kuliah, para mahasiswa ini akan menjalankan masa pengabdian selama satu tahun di daerah pedalaman untuk membina masyarakat.

Di Indonesia sudah banyak lembaga zakat maupun lembaga sosial lainnya yang mengelola dana dari masyarakat tetapi penelitian tentang perhitungan dampak sosial dari pengolaan dana tersebut belum banyak dilakukan. Hal ini membuka semakin besarnya peluang untuk dilakukan perhitungan dampak sosial. Oleh karena itu pengukuran terhadap dampak sosial yang ditimbulkan oleh STID MOHAMMAD NATSIR perlu dilakukan. Dampak dari pengelolaan dana ZISWAF yang dilakukan oleh STID MOHAMMAD NATSIR dapat dijadikan sebagai pedoman dan tolak ukur lembaga tersebut maupun lembaga pendidikan sejenisnya dalam menyelenggarakan programnya dan meningkatkan mutu kegiatan sosialnya.

Berdasarkan latar belakang tersebut, maka penulis tertarik untuk meneliti seberapa besar dampak sosial yang dihasilkan dari pengelolaan dana ZISWAF oleh STID MOHAMMAD NATSIR dalam penelitian berjudul: Dampak Penyaluran Dana Ziswaf (Zakat, Infaq, Sedekah Dan Wakaf) Pada Program Pendidikan STID Mohammad Natsir Berdasarkan Social Return On Investment.

\section{HASIL DAN DISKUSI}




\section{Temuan Penelitian}

\section{Gambaran Umum dan Sejarah STID Mohammad Natsir}

Sekolah Tinggi Ilmu Da'wah (STID) Mohammad Natsir sebagai salah satu mata rantai perjuangan umat Islam serta dalam rangka turut membangun dan membina peradaban melalui Islamisasi ilmu \& kampus serta penyiaran tsaqafah Islamiyah serta sebagai gerakan pendidikan untuk melahirkan sumber daya manusia, baik dari segi kuantitas maupun kualitas berupa kader-kader pemikir muslim dan pemimpin ummat yang mengenal ajaran dan nilai-nilai Islam serta berkemampuan menyebarkan dan menumbuhkannya dalam berbagai aspek kehidupan

STID Mohammad Natsir merupakan kelanjutan dari lembaga pendidikan yang pernah ada dilingkungan Dewan Da'wah Islamiyah Indonesia, yaitu Akademi Bahasa Arab (AKBAR) dan Lembaga Pendidikan Da'wah Islam (LPDI). Setelah mengalamii vakum, maka berdasarkan hasil Musyawarah Besar (MUBES) ke-2 Dewan Da'wah Islamiyah Indonesia pada tanggal 12-14 Juni 1998 di Jakarta memutuskan untuk meningkatkan program LPDI dari program D2 menjadi program Strata Satu (S1).

\section{Visi dan Misi STID Moh. Natsir}

Visi : Menjadi pusat kaderisasi da’i untuk pengembangan da'wah Islam atas dasar iman dan takwa menuju terciptanya ketahanan ummat dan bangsa.

\section{Misi}

1. Menyelenggarakan pendidikan dan pengajaran yang berlandaskan $\mathrm{Al}$ Qur'an dan As Sunnah menurut pemahaman Rasulullah dan para sahabat.

2. Melaksanakan penelitian da'wah yang berorientasi pada pemecahan problematika keummatan dan bangsa.

3. Melaksanakan pelayanan kepada masyarakat yang berbasis penyiaran dan teori pengembangan masyarakat Islam.

\section{Tujuan Pendidikan}

1. Melahirkan da'i yang memiliki integritas sebagai da'i ilallah

2. Melahirkan da'i yang menguasai ulum al din dan ad da'wah 
3. Melahirkan da'i yang memiliki skill komunikasi dan da'wah

\section{Program Studi STID Moh. Natsir}

Dalam kurikulum pendidikannya STID Moh Natsir memiliki dua program studi (prodi) yakni :

1. Program Studi Komunikasi dan Penyiaran Islam (KPI)

2. Program Studi Pengembangan Masyarakat Islam (PMI)

\section{Pesantren Mahasiswa}

Pada 2 (dua) tahun pertama (semester I-IV) mahasiswa diwajibkan tinggal di Pesantren Mahasiswa untuk mendalami beberapa materi utama dengan sistem Talaqqi dan Mulazamah. Materi tersebut adalah:

1. Bahasa Arab

2. Tahfizh al-Qur'an, Hadits, dan Qaul Ulama'

3. Pembinaan Karakter Da'i Ilallah

4. Penguasaan Kitab-Kitab Turats

5. Skill dan Ilmu Da'wah

Materi-materi tersebut harus dikuasai sebagai syarat untuk dapat melanjutkan perkuliahan pada tahun berikutnya.

Sementara pada 2 (dua) Tahun Kedua ( Semester V-VIII), mahasiswa sudah tidak diperkenankan tinggal di Pesantren Mahasiswa. Mahasiswa diwajibkan tinggal di persekitaran kampus dalam program KPM (Kafilah Pecinta Masjid), mendalami materi spesialisasi bersama para tokoh da'wah dan ilmuwan, melaksanakan magang di kantor Dewan Da'wah Pusat serta melaksanakan Kafilah Da'wah di daerah pedalaman selama 2 bulan. Model perkuliahan ini bertujuan agar mahasiswa dapat berlatih sekaligus praktek membina umat sebagai bekal untuk melaksanakan pengabdian da'wah setelah lulus kuliah selama satu tahun.

\section{KPM (Komunitas Pecinta Masjid)}

Merupakan sebuah Komunitas Mahasiswa yang berpusat di masjid. Komunitas ini dibentuk sebagai bagian dari proses pembinaan mahasiswa 
yang bertujuan untuk melatih Mahasiswa di dalam mewujudkan cita-cita menjadikan masjid sebagai pusat kegiatan ummat berdasarkan petunjuk Allah dan Rasul-Nya. Komunitas Pecinta Masjid atau disingkat dengan KPM Mahasiswa Sekolah Sekolah Tinggi Ilmu Da'wah Mohammad Natsir. KPM adalah salah satu bentuk pembinaan yang wajib dilakukan oleh mahasiswa STID Mohammad Natsir dalam ranah pengabdian dan pelatihan yang berbasis masjid.

\section{Kafilah Da'wah}

Kafilah Da'wah merupakan salah satu program kurikulum STID Mohammad Natsir yang bertujuan untuk meningkatkan kualitas mahasiswa dalam skill da'wah, maka kampus STID Mohammad Natsir dibawah pengawasan Waket Bidang Kemahasiswaan mengadakan satu program tahunan yang dinamakan dengan "Kafilah Da'wah". Kegiatan ini bersifat wajib bagi setiap angkatan. Program Kafilah Da'wah dilakukan oleh mahasiswa dalam bentuk kegiatan da'wah di suatu wilayah yang ditentukan oleh STID Mohammad Natsir baik sebelum maupun setelah mendapatkan usulan dari calon peserta Kafilah Da'wah maupun dari pihak lain. Wilayah yang menjadi prioritas pelaksanaan kegiatan ini adalah daerah pedesaan, daerah terpencil/pedalaman, daerah muslim minoritas, daerah transmigrasi serta daerah perbatasan Indonesia dengan negeri tetangga.

\section{Program Dakwah Pedalaman}

Sebelum lulus di STID Mohammad Natsir, mahasiswa wajib melakukan pengabdian da'wah setahun. Mahasiswa ditugaskan ke berbagai daerah pedalaman, perbatasan, terpencil, dan suku terasing. Program ini adalah warisan pendiri Dewan Dakwah, Dr. Mohammad Natsir. Program pengabdian da'wah pedalaman ini sudah tersebar hampir di seluruh Indonesia. Seperti di Kalimatan, Jawa, Sulawesi, Maluku, Sumatera, dan Papua. Untuk wilayah timur, NTT dan NTB.

Para dai yang ditugaskan tidak hanya dibekali ilmu agama saja, namun juga ilmu di dalam bersosialisasi dan beriteraksi dengan masyarakat setempat. Tugas para dai juga melakukan pemberdayaan masyarakat guna meningkatkan ekonomi dan pengetahuan masyarakat misalnya di bagian cocok tanam, ternak dan sebagainya. Para dai yang ditugaskan di daerah 
pedalaman seperti di bagian timur melakukan pemberdayaan ternak sapi. Sedangkan di Mentawai mereka bercocok tanam, terutama padi.

Para da'i juga melakukan sejumlah program pengembangan masyarakat binaan, antara lain: Saatnya Da’i Dibekali, Da'i Datang Desaku Terang, Da'i Datang Desaku Rindang, Da'i Datang Perbatasan Tenang, Ternak Sehat, Bantuan Pertanian, Wakaf Al-Qur'an, Pelatihan Iqra', Wakaf Sumur buat Sedulur, Respon Darurat Korban Bencana Alam \& Kemanusiaan, dan Qurban Multimanfaat.

Masa tugas mereka biasanya satu sampai dua tahun. Lalu, mereka digantikan rekan lainnya. Mereka membuat dan mengaktifkan berbagai kegiatan keislaman melalui majelis taklim serta membina mualaf. Dakwah merupakan salah satu kewajiban utama sesuai tuntutan Al-Quran dan hadis. Itulah tugas mulia umat di dunia, yakni menyebarkan risalah Ilahi (Natsir, 2019).

\section{Identitas Responden}

Dalam penelitian ini, responden yang dijadikan sebagai informan kunci adalah katua Biro Dikti dari Bidang Pendidikan Dewan Da'wah Pusat, Ketua STID Mohammad Natsir, Ketua Biro Da’i Dewan Da'wah dari Bidang Da'wah Pusat, Kepala Kemahasiswaan dan Biro Adminitrasi Umum dan Keuangan (BAUK). Selain itu, responden yang dijadikan informan selanjutnya adalah para alumni yang berasal dari angkatan 2010 2018 yang telah menyelesaikan tugas Da'wah pedalamannya. Alumni STID Mohammad Natsir yang dijadikan responden yakni sebanyak 15 orang dan 3 orang diantaranya dijadikan narasumber wawancara. Selain manajemen dan alumni STID Mohammad Natsir, 4 orang masyarakat sekitar yang dipekerjakan di STID Mohammad Natsir juga turut menjadi responden dalam penelitian ini.

\section{Social Return on Investment STID Mohammad Natsir}

\section{Menetapkan Ruang Lingkup dan Mengidentifikasi Stakeholder}

Menetapkan Ruang Lingkup

1) Tujuan 
Tujuan dari analisis SROI ini adalah untuk mengidentifikasi nilai sosial yang dihasilkan dari STID Mohammad Natsir. Analisis ini dilakukan untuk membuat para pemangku kepentingan dapat lebih termotivasi untuk menyalurkan ZISWAF ke lembaga amil zakat yang menghasilkan dampak sosial dan membuat penerima manfaat memahami apa manfaat yang mereka dapatkan.

2) Audiensi

Hasil dari analisis dapat digunakan sebagai bahan evaluasi yang selanjutnya bisa berguna dalam pengembangan program STID Mohammad Natsir dan juga berguna bagi stakeholder untuk melihat nilai yang diciptakan dari Program STID Mohammad Natsir tersebut.

\section{3) Background}

Tujuan dari penelitian ini adalah untuk menghitung nilai sosial yang diciptakan dari program STID Mohammad Natsir. Dengan dilakukannya analisis ini STID Mohammad Natsir akan memiliki informasi lebih lanjut tentang nilai sosial dan lingkungan yang dapat dihasilkan dari kegiatan yang dilakukan.

\section{4) Resources}

Pihak STID Mohammad Natsir telah menyediakan waktu untuk wawancara dan memberikan arahan untuk mengisi kuesioner online kepada para alumni, serta juga memberikan berbagai dokumen internal yang diperlukan. Pihak manajemen STID Mohammad Natsir juga telah menemani untuk melakukan wawancara secara langsung dengan para staff karyawan dan pihak Dewan Da'wah Pusat yang terlibat dalam program STID Mohammad Natsir.

5) Kegiatan yang akan menjadi fokus

Penelitian ini fokus pada kegiatan yang dilakukan oleh Kampus B STID Mohammad Natsir yang bertempat di Jalan Kampung Bulu No.4, Setiamekar, Tambun Selatan, Setiamekar, Kec. Tambun Sel., Bekasi, Jawa Barat 17510.

6) Periode waktu yang diteliti : Satu tahun (2018)

7) Apakah analisis adalah forecast atau evaluation? 
Analisis SROI yang dilakukan adalah analisis Evaluation. Analisis evaluation merupakan analisis yang dilakukan kepada program atau proyek yang sudah dilakukan atau sedang berjalan.

\section{a. Mengidentifikasi Stakeholder Kunci}

Selama melakukan penelitian ditemukan kelompok yang berbeda dari pemangku kepentingan. Ada yang terkena dampak langsung dan ada yang tidak. Stakeholder kunci adalah orang-orang yang terkena dampak dari kegiatan yang dilaksanakan sedangkan stakeholder yang dikecualikan (exclude stakeholders) adalah mereka yang tidak terkena dampak atau manfaat dari kegiatan yang dilaksanakan.

Tabel 4.2 Analisis Stakeholder

\begin{tabular}{|l|l|}
\hline \multicolumn{1}{|c|}{ Key Stakeholders } & \multicolumn{1}{c|}{ Deskripsi } \\
\hline $\begin{array}{l}\text { Manajemen STID Mohammad } \\
\text { Natsir }\end{array}$ & $\begin{array}{l}\text { Beberapa kegiatan di STID } \\
\text { Mohammad Natsir dilakukan oleh } \\
\text { manajemen STID Mohammad } \\
\text { Natsir }\end{array}$ \\
\hline $\begin{array}{l}\text { Manajemen Dewan Da'wah } \\
\text { Pusat }\end{array}$ & $\begin{array}{l}\text { Beberapa program wajib untuk } \\
\text { mahasiswa di STID Mohammad } \\
\text { Natsir dilakukan oleh manajemen } \\
\text { Dewan Dawah Pusat }\end{array}$ \\
\hline $\begin{array}{l}\text { Alumni STID Mohammad } \\
\text { Natsir }\end{array}$ & $\begin{array}{l}\text { Dampak yang dihasilkan dirasakan } \\
\text { manfaatnya secara langsung oleh } \\
\text { alumni STID Mohammad Natsir }\end{array}$ \\
\hline Karyawan (Masyarakat Sekitar) & $\begin{array}{l}\text { Masyarakat sekitar yang menjadi } \\
\text { karyawan di STID Mohammad } \\
\text { Natsir juga merasakan manfaatnya }\end{array}$ \\
\hline Masyarakat Pedalaman & $\begin{array}{l}\text { Masyarakat pedalaman yang } \\
\text { menjadi objek dakwah pada } \\
\text { program STID Mohammad Natsir } \\
\text { juga merasakan Manfaatnya }\end{array}$ \\
\hline \multicolumn{1}{|c|}{ Exclude Stakeholder } & \multicolumn{1}{c|}{ Deskripsi } \\
\hline
\end{tabular}




\begin{tabular}{|l|l|}
\hline Pemerintah Lokal & Berperan dalam penyandang \\
& pemberi bantuan untuk STID \\
& Mohammad Natsir, tapi perannya \\
tidak terlalu signifikan terhadap & perubahan yang dihasilkan \\
\hline Donatur & Berperan dalam mendonasikan \\
& dana untuk kegiatan STID \\
& Mohammad Natsir, tapi perannya \\
& tidak terlalu signifikan terhadap \\
& perubahan. \\
\hline
\end{tabular}

Proses identifikasi pemangku kepentingan dilakukan dengan melakukan wawancara di tahap awal. Dalam penelitian ini fokus utama adalah 15 orang alumni STID Mohammad Natsir. Untuk alumni diberikan kuesioner online dan wawancara sedangkan untuk pihak manajemen STID Mohammad Natsir dilakukan wawancara secara langsung.

b. Memutuskan Bagaimana Melibatkan Stakeholder

Tabel 4.3 Metode Pelibatan Stakeholder

\begin{tabular}{|c|c|c|c|}
\hline Stakeholders & $\begin{array}{c}\text { Metode } \\
\text { Pelibatan }\end{array}$ & $\begin{array}{l}\text { Jumlah } \\
\text { (Orang) }\end{array}$ & Tanggal \\
\hline $\begin{array}{l}\text { Manajemen stid } \\
\text { Mohammad Natsir } \\
\text { (Ketua STID } \\
\text { Mohammad Natsir, } \\
\text { Ketua Biro BAUK, } \\
\text { Kepala } \\
\text { Kemahasiswaan) }\end{array}$ & $\begin{array}{l}\text { Wawancara } \\
\text { langsung }\end{array}$ & 3 & $\begin{array}{c}19 \text { - } \\
\text { 21 Agustus } \\
2019\end{array}$ \\
\hline $\begin{array}{l}\text { Manajemen Dewan } \\
\text { Da'wah Islamiyah } \\
\text { Indonesia Pusat } \\
\text { (Bidang Pendidikan } \\
\text { \& Bidang Da'wah) }\end{array}$ & $\begin{array}{l}\text { Wawancara } \\
\text { Langsung }\end{array}$ & 2 & $\begin{array}{c}19-23 \\
\text { Agustus } 2019\end{array}$ \\
\hline $\begin{array}{l}\text { Alumni STID } \\
\text { Mohammad Natsir }\end{array}$ & $\begin{array}{l}\text { Wawancara } \\
\text { Online dan }\end{array}$ & 3 dan 15 & $\begin{array}{c}16-23 \\
\text { Agustus } 2019\end{array}$ \\
\hline
\end{tabular}




\begin{tabular}{|l|l|l|c|}
\hline & $\begin{array}{l}\text { kuesioner } \\
\text { Online }\end{array}$ & & \\
\hline $\begin{array}{l}\text { Karyawan } \\
\text { (Masyarakat Sekitar) }\end{array}$ & $\begin{array}{l}\text { Wawancara } \\
\text { Langsung }\end{array}$ & 4 & $\begin{array}{c}21 \text { Agustus } \\
2019\end{array}$ \\
\hline
\end{tabular}

\section{Memetakan Dampak}

Dalam penelitian yang dilakukan oleh (The SROI, 2012) Pada bagian ini dilakukan pembuatan peta dampak mulai dari proses hingga perhitungan rasio. Analisis dilakukan dengan pelibatan para pemangku kepentingan untuk memastikan bahwa hasil tersebut relevan. Dalam memetakan dampak dilibatkan 5 informan kunci yang terdiri dari bidang pendidikan Dewan Da'wah Pusat, Bidang Da'wah Dewan Da'wah Pusat, Ketua STID Mohammad Natsir, Ketua BAUK, kepala Kemahasiswaan dan 3 orang alumni STID Mohammad Natsir. Data dikumpulkan dengan melakukan wawancara. Pertanyaan yang diajukan sesuai dengan panduan SROI:

1. Apa arti perubahan bagi anda?

2. Seberapa penting perubahan bagi anda?

3. Apakah anda bisa mengakses program lain untuk mendapatkan hasil yang sama? Jika ada apa programnya?

4. Apakah anda mengikuti program lain yang memberikan kontribusi terhadap perubahan yang anda alami? Jika ada apa jenis programnya?

5. Jika anda mengikuti program lain yang mungkin telah memberikan kontribusi terhadap perubahan yang anda alami, berapa banyak kontribusi terhadap perubahan tersebut?

6. Apa pendapat anda jika anda tidak bergabung dengan STID Mohammad Natsir?

Berdasarkan hasil diskusi awal dengan informan kunci maka dapat dibuat teori perubahan yang dialami oleh alumni STID Mohammad Natsir, masyarakat sekitar dan masyarakat pedalaman (Gambar 4.1). 
13 | Jurnal Bina Ummat | Vol.2 | No.1| 2019 
Gambar 4.1 Teori Perubahan

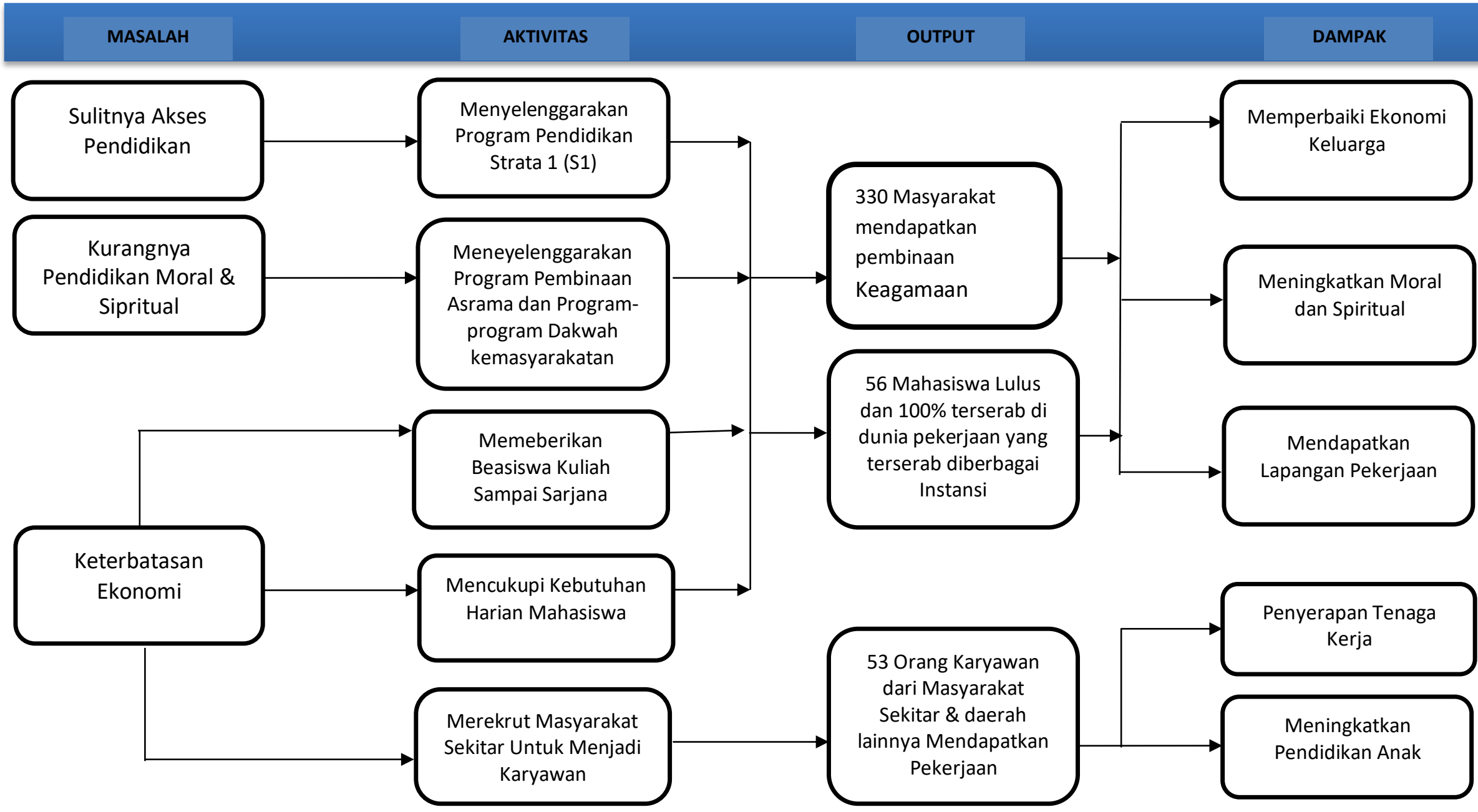


Berikut proses dalam tahapan memetakan dampak yang telah diciptakan oleh STID Mohammad Natsir:

a. Mulai Pada Peta Dampak

Peta dampak adalah lembaran kerja inti yang berisi susunan sistematis dari analisis yang telah dilakukan. Peta dampak dibuat untuk membedakan hasil dari setiap stakeholder dari kegiatan tersebut. Peta dampak berisi gambaran hasil dari analisis SROI.

b. Mengidentifikasi Input

Input di dalam SROI terdiri dari tiga jenis yaitu uang, waktu dan barang. Input yang dikeluarkan oleh STID Mohammad Natsir adalah biaya kurikulum, biaya kemahasiswaan, biaya asrama, biaya program-program dakwah pembinaan masyarakat dan biaya umum langsung.

Tabel 4.4 Input Stakeholder

\begin{tabular}{|c|l|}
\hline \multicolumn{1}{|c|}{ Stakeholder } & \multicolumn{1}{c|}{ Input } \\
\hline Manajemen STID Mohammad Natsir & 1. Biaya Kurikulum \\
& 2. Biaya Asrama \\
& 3. Biaya Kerumah Tanggaan \\
& 4. Biaya Kesehatan Staff Karyawan \\
& 5. Biaya Gaji Staff Karyawan \\
& 6. Biaya Pelatihan Karyawan \\
\hline
\end{tabular}

c. Menilai Input

Input yang dikeluarkan oleh STID Mohammad Natsir akan dilakukan penilaian. Pemberian nilai ini adalah proses mengkonversikan input tersebut kenilai uang. Analisis yang dilakukan menggunakan data yang ditemukan dilapangan dan mengkonversinya ke harga pasar.

\section{d. Mengklarifikasi Output}

Output menunjukan sebuah dampak yang segera dapat terlihat/dirasakan dari adanya sebuah program atau proyek. Dari analisis yang telah dilakukan melalui wawancara dan survey dilapangan, output dari kegiatan yang dilakukan oleh STID Mohammad Natsir adalah meluluskan 56 mahasiswa dan 100\% alumni diantaranya dikirim ke daerah pedalaman dan kampung masing-masing untuk menjalankan tugas perjanjian terikat sebelumnya untuk mengabdi dan membina masyarakat dalam meningkatkan moral dan spiritualitasnya.

e. Menggambarkan Outcome

SROI merupakan sebuah teknik yang dikembangkan untuk berfokus kepada stakeholder dalam setiap tahapan prosesnya. Manfaat yang dihasilkan dari kegiatan yang dilakukan oleh STID Mohammad Natsir dianalisis dengan mendengarkan setiap pendapat stakeholder tentang setiap perubahan dan manfaat yang mereka rasakan.

Kegiatan pendidikan yang dilaksanakan oleh STID Mohammad Natsir dicirikan dengan kegiatan yang mengandung nilai keagamaan guna melahirkan pengkaderan seorang Da'i Ilallah yang memiliki spiritualitas Da'i sejati yang berkualitas. STID Mohammad Natsir 
merekrut calon peserta didik dari berbagai kalangan; mulai dari prasejahtera sampai kalangan kebawah yang memiliki kemauan untuk di kader sebagai Da’i. STID Mohammad Natsir merekrut calon peserta didik dari seluruh Indonesia melalui panitia penerimaan peserta mahasiwa baru (Panitia PMB) dan kantor cabang Dewan Dakwah di berbagai daerah yang tidak dapat dijangkau oleh panitia PMB.

Selain merekrut calon mahasiswa dari berbagai daerah, STID Mohammad Natsir juga merekrut karyawan dari masyarakat sekitar STID Mohammad Natsir. STID Mohammad Natsir merekrut masyarakat sekitar dalam upaya pemberdayaan dan pembukaan lapangan pekerjaan. Masyarakat sekitar yang direkrut oleh STID Mohammad Natsir mayoritas ditempatkan di bagian umum seperti library, gardener dan maintenance.

Penetapan dilakukan menggunakan pembuatan teori perubahan yang didiskusikan dengan stakeholder. Berikut dampak dari kegiatan yang dilakukan oleh STID Mohammad Natsir:

Tabel 4.5 Penetapan Dampak

\begin{tabular}{|c|c|c|c|}
\hline Stakeholder & Aktivitas & Output & Outcome \\
\hline $\begin{array}{l}\text { Alumni STID } \\
\text { Mohammad } \\
\text { Natsir }\end{array}$ & $\begin{array}{l}\text { Pendidikan } \\
\text { Akademik dan } \\
\text { Asrama }\end{array}$ & $\begin{array}{l}56 \text { dan } 100 \% \\
\text { alumninya } \\
\text { mengabdi untuk } \\
\text { membina } \\
\text { masyarakat } \\
\text { pedalaman dan } \\
100 \% \text { dari alumni } \\
\text { sebelumnya } \\
\text { terserap di dunia } \\
\text { pekerjaan }\end{array}$ & $\begin{array}{l}\text { 1. Memperbaiki } \\
\text { ekonomi keluarga } \\
\text { 2. Meningkatkan moral } \\
\text { dan spiritual } \\
\text { 3. Mendapat lapangan } \\
\text { pekerjaan }\end{array}$ \\
\hline $\begin{array}{l}\text { Masyarakat } \\
\text { Sekitar dan } \\
\text { Staff Karyawan }\end{array}$ & $\begin{array}{l}\text { Diberdayakan di } \\
\text { bagian umum ( } \\
\text { Gardener, } \\
\text { maintenance, } \\
\text { perpustakaan) dan } \\
\text { staff karyawan }\end{array}$ & $\begin{array}{l}53 \text { orang } \\
\text { karyawan dari } \\
\text { masayarakat } \\
\text { sekitar dan daerah } \\
\text { lainnya } \\
\text { mendapatkan } \\
\text { pekerjaan }\end{array}$ & $\begin{array}{l}\text { 1. Meningkatkan } \\
\text { moral dan spiritual } \\
\text { masyarakat } \\
\text { 2. Penyerapan tenaga } \\
\text { kerja } \\
\text { 3. Meningkatkan } \\
\text { pendidikan anak }\end{array}$ \\
\hline
\end{tabular}

Analisis SROI merupakan metoda yang mengukur konsep nilai yang lebih luas meliputi nilai sosial, ekonomi dan lingkungan. Berikut gambar pengelompokan dampak yang di alami oleh stakeholder STID Mohammad Natsir akibat dari kegiatan yang dilaksanakan.

Gambar 4.2 Klasifikasi Dampak

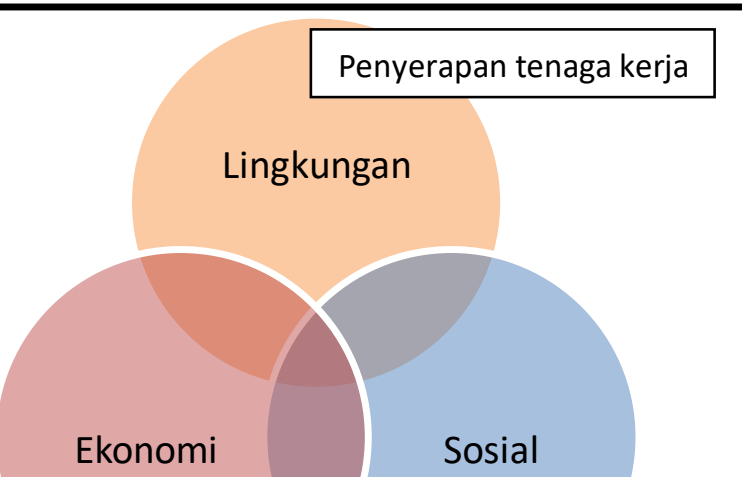




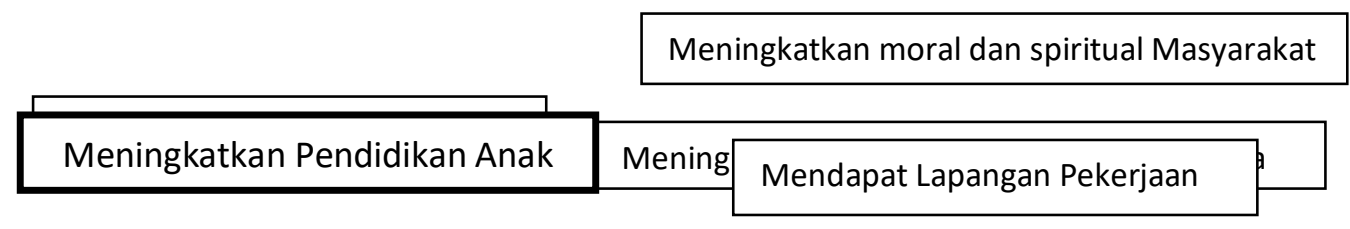

\section{Membuktikan Adanya Dampak dan Meberinya Nilai}

Pada tahapan ini, analisis yang dilakukan adalah menentukan indikator dari dampak yang dihasilkan. Indikator tersebut digunakan untuk menentukan nilai dari dampak tersebut.

f. Mengembangkan Indikator Hasil

Pada tahapan ini dijelaskan megenai bukti bahwa dampak ditimbulkan benar-benar terjadi dan dirasakan oleh mahasiswa dan masyarakat sekitar/karyawan. Bukti tersebut di dalam analisis SROI dikenal dengan indikator. Indikator adalah cara untuk mengetahui perubahan yang telah terjadi. Indikator diperlukan untuk menjelaskan mengenai dampak yang ada dan seberapa banyaknya. Indikator dapat bersifat subyektif atau objektif. Indikator subyektif adalah indikator yang berasal dari pengalaman yang dirasakan seseorang atau pendapat seseorang yang dijadikan fakta terjadinya perubahan. Dalam analisis ini, indikator yang digunakan adalah indikator subyektif karena indikator tersebut berasal dari pengalaman serta pendapat siswa dan masyarakat sekitar/karyawan. Indikator objektif juga digunakan seperti data jumlah lulusan STID Mohammad Natsir yang terserap di dunia pekerjaan, masyarakat pedalaman yang mendapatkan manfaat dari pembinaan keagamaan dan pemberdayaan masyarakat serta jumlah masyarakat sekitar dan umum yang dipekerjakan oleh STID Mohammad Natsir. Tabel berikut menjelaskan indikator dari masing-masing dampak yang dirasakan oleh mahasiswa dan masyarakat sekitar/karyawan.

Tabel 4.6 Pengembangan Indikator Hasil

\begin{tabular}{|c|c|c|}
\hline Dampak & Deskripsi Dampak & Indikator \\
\hline
\end{tabular}




\begin{tabular}{|c|c|c|}
\hline $\begin{array}{l}\text { Memperbaiki ekonomi } \\
\text { keluarga }\end{array}$ & $\begin{array}{l}\text { 1. Beban orangtua } \\
\text { mahasiswa untuk } \\
\text { menyekolahkan dan } \\
\text { mencukupi kebutuhan } \\
\text { anaknya berkurang }\end{array}$ & $\begin{array}{l}\text { 1. Jumlah mahasiswa } \\
\text { STID Mohammad } \\
\text { Natsir }\end{array}$ \\
\hline $\begin{array}{l}\text { Mendapatkan } \\
\text { Lapangana pekerjaan }\end{array}$ & $\begin{array}{l}\text { Alumni STID Mohammad } \\
\text { Natsir yang terserab di } \\
\text { dunia pekerjaan }\end{array}$ & $\begin{array}{l}\text { Jumlah alumni yang } \\
\text { mendapatkan pekerjaan } \\
\text { dari berbagai instansi }\end{array}$ \\
\hline $\begin{array}{l}\text { Meningkatkan moral } \\
\text { dan spiritual } \\
\text { Mahasiswa }\end{array}$ & $\begin{array}{l}\text { Mahaiswa mendapatkan } \\
\text { pembinaan asrama untuk } \\
\text { melatih moral, } \\
\text { kemampuan interpersonal } \\
\text { dan menambah } \\
\text { pengetahuan agama } \\
\text { Masyarakat mendapatkan } \\
\text { pembinaan keagaman dari } \\
\text { Da'i, alumni STID } \\
\text { Mohammad Natsir yang } \\
\text { bertugas dakwah } \\
\text { pedalaman }\end{array}$ & $\begin{array}{l}\text { Jumlah mahasiswa yang } \\
\text { mendapatkan } \\
\text { pembinaan asrama oleh } \\
\text { STID Mohammad } \\
\text { Natsir } \\
\text { Jumlah masyarakat yang } \\
\text { mendapatkan } \\
\text { pembinaan keagamaan } \\
\text { dari Da’i, alumni STID } \\
\text { Mohammad Natsir yang } \\
\text { bertugas dakwah } \\
\text { pedalaman }\end{array}$ \\
\hline $\begin{array}{l}\text { Penyerapan tenaga } \\
\text { kerja }\end{array}$ & $\begin{array}{l}\text { STID Mohammad Natsir } \\
\text { memepekerjakan } \\
\text { masyarakat sekitar sebagai } \\
\text { bagian umum (Library, } \\
\text { Gardener dan Maintenance) } \\
\text { Dan juga beberapa staff } \\
\text { karyawan yang berasal dari } \\
\text { berbagai daerah }\end{array}$ & $\begin{array}{l}\text { Jumlah masyarakat } \\
\text { sekitar dan sejumlah } \\
\text { staff karyawan yang } \\
\text { berasal dari berbagai } \\
\text { daerah dipekerjakan } \\
\text { oleh STID Mohammad } \\
\text { Natsir }\end{array}$ \\
\hline $\begin{array}{l}\text { Meningkatkan } \\
\text { pendidikan anak }\end{array}$ & $\begin{array}{l}\text { Staff Karyawan yang } \\
\text { dipekerjakan oleh STID } \\
\text { Mohammad Natsir dapat } \\
\text { membiayai pendidikan } \\
\text { anaknya }\end{array}$ & $\begin{array}{l}\text { Jumlah anak staff } \\
\text { karyawan yang sekolah } \\
\text { dengan pembiayaan dari } \\
\text { pendapatan bekerja di } \\
\text { STID Mohammad } \\
\text { Natsir }\end{array}$ \\
\hline
\end{tabular}

g. Mengumpulkan Data Dampak

Data dikumpulkan melalui kuesioner dan wawancara. Wawancara dilakukan kepada informan kunci yaitu pihak manajemen STID Mohammad Natsir seperti Bidang Pendidikan Dewan Da'wah Pusat, Bidang Da'wah Dewan Da'wah Pusat, Kutua STID Mohammad Natsir, Ketua Biro Administrasi Umum dan Keuanagan (BAUK), kepala asrama, Alumni STID Mohammad Natsir dan karyawan yang berasal dari masyarakat sekitar kampus dan Staff Karyawan dari berbagai daerah lainnya. Wawancara dilakukan secara langsung. Selama 
wawancara diberikan pertanyaan. Wawancara dilakukan secara langsung dan satu persatu. Para alumni juga diberi kuesioner yang berisi pertanyaan-pertanyaan singkat.

h. Menentukan Berapa Lama Dampak Berlangsung

Dalam buku panduan (Nicholls et al., 2012) SROI maksimum durasi waktu yang diterapkan dalam analisis adalah lima tahun dan minimum satu tahun. Dampak di dalam penelitian ini berlangsung selama lima tahun dan dihitung dengan durasi lima tahun.

i. Menetapkan Nilai Dampak

Pada tahap ini dilakukan penilaian terhadap dampak yaitu memberikan nilai uang terhadap dampak yang terjadi. Penilaian dilakukan menggunakan proksi keuangan. Menguangkan dampak merupakan salah satu kelebihan SROI yang tidak dimiliki alat analisis yang lain. Penetapan proksi keuangan ini dilakuakan berdasarkan metode penetapan proksi yang merujuk pada report SROI.

Tabel 4.7 Penetapan Proksi Keuangan

\begin{tabular}{|c|c|c|}
\hline Dampak & Indikator & Proksi Keuangan \\
\hline $\begin{array}{l}\text { Memperbaiki } \\
\text { ekonomi } \\
\text { keluarga }\end{array}$ & $\begin{array}{l}\text { Jumlah mahasiswa STID } \\
\text { Mohammad Natsir }\end{array}$ & $\begin{array}{l}\text { Biaya yang dikeluarkan } \\
\text { oleh orangtua untuk } \\
\text { membiayai kuliah dan } \\
\text { kebutuhan harian }\end{array}$ \\
\hline $\begin{array}{l}\text { Mendapatkan } \\
\text { Lapangana } \\
\text { pekerjaan }\end{array}$ & $\begin{array}{l}\text { Jumlah alumni STID } \\
\text { Mohammad Natsir yang telah } \\
\text { mendapatkan pekerjaan }\end{array}$ & $\begin{array}{l}\text { Gaji pekerjaan yang di } \\
\text { dapatkan selama bekerja }\end{array}$ \\
\hline $\begin{array}{l}\text { Meningkatkan } \\
\text { moral dan } \\
\text { spiritual } \\
\text { Mahasiswa }\end{array}$ & $\begin{array}{l}\text { Jumlah mahasiswa yang } \\
\text { mendapatkan pembinaan } \\
\text { asrama oleh STID Mohammad } \\
\text { Natsir }\end{array}$ & $\begin{array}{l}\text { Biaya pembinaan asrama } \\
\text { dan jumlah waktu } \\
\text { mahasiswa yang mengikuti } \\
\text { pembinaan asrama }\end{array}$ \\
\hline $\begin{array}{l}\text { Meningkatkan } \\
\text { moral dan } \\
\text { spiritual } \\
\text { Masyarakat }\end{array}$ & $\begin{array}{l}\text { Dan jumlah masyarakat } \\
\text { pedalaman yang mendapatkan } \\
\text { pembinaan keagamaan dari para } \\
\text { alumni yang bertugas } \\
\text { pengandian dakwah pedalaman } \\
\text { di daerah pedalaman }\end{array}$ & $\begin{array}{l}\text { Biaya pembinaan } \\
\text { keagamaan dan jumlah } \\
\text { waktu masyarakat } \\
\text { pedalaman yang mengikuti } \\
\text { pembinaan keagaman }\end{array}$ \\
\hline $\begin{array}{l}\text { Penyerapan } \\
\text { tenaga kerja }\end{array}$ & $\begin{array}{l}\text { 1. Jumlah masyarakat sekitar } \\
\text { kampus yang dipekerjakan oleh } \\
\text { STID Mohammad Natsir } \\
\text { 2. Dan jumlah staff karyawan } \\
\text { yang dipekerjakan dari berbagai } \\
\text { daerah oleh STID Mohammad } \\
\text { Natsir }\end{array}$ & $\begin{array}{l}\text { Gaji yang diterima } \\
\text { karyawan umum dan staff } \\
\text { karyawan oleh STID } \\
\text { Mohammad Natsir }\end{array}$ \\
\hline
\end{tabular}




\begin{tabular}{|l|l|l|}
\hline $\begin{array}{l}\text { Meningkatkan } \\
\text { pendidikan }\end{array}$ & $\begin{array}{l}\text { Jumlah anak staff karyawan } \\
\text { anakg sekolah dengan }\end{array}$ & $\begin{array}{l}\text { Pembiayaan yang tertutupi } \\
\text { selama setahun }\end{array}$ \\
& $\begin{array}{l}\text { pembiayaan dari pendapatan } \\
\text { bekerja di STID Mohammad }\end{array}$ & \\
Natsir & \\
\hline
\end{tabular}

\subsubsection{Menetapkan Dampak}

Pada tahapan ini dilakukan penilaian dampak terkait dengan prinsip SROI yaitu jangan berlebihan (do-not overclaim). Pada dasarnya pada tahapan ini adalah untuk meyakinkan bahwa nilai yang telah ditetapkan untuk suatu dampak tidak terlalu tinggi dan benar-benar mencerminkan nilai yang sebenarnya (Nicholls et.al., 2012, hlm. 54).

\section{a. Deadweight}

Deadweight merupakan persentase seberapa besar dampak tersebut tetap terjadi tanpa perlu adanya suatu program/proyek. Deadweight untuk semua dampak dalam penilitian ini diperoleh sebesar nol persen $(0 \%)$ didasarkan pada wawancara dengan mahasiswa yang mengungkapkan bahwa mereka tidak akan medapatkan manfaat apabila tidak ada STID Mohammad Natsir.

\section{b. Displacement}

Displacement mengacu pada relokasi perubahan dari luar ke dalam proyek. Displacement pada dasarnya menjawab pertanyaan apakah ada kegiatan positif lain yang justru tergantikan setelah adanya program atau proyek. Di dalam analisis SROI ini, displacement diperoleh sebesar nol persen $(0 \%)$. Hal ini didasarkan pada wawancara dengan mahasiswa yang mengungkapkan bahwa tidak ada kegiatan positif yang tergantikan oleh program STID Mohammad Natsir ini.

\section{c. Attribution}

Atrribution adalah penilaian dari seberapa banyak hasil tersebut disebabkan oleh kontribusi dari orang atau organisasi lain. Dari hasil wawancara dengan siswa bahwa mereka sering mendapatkan pelatihan kepemimpinan dari pihak lain selain STID Mohammad Natsir. Hal ini mengindikasikan bahwa adanya kontribusi dari kegiatan atau pihak lain terhadap dampak yang terjadi. Persentase dari kontribusi kegiatan/pihak lain tersebut kecil. Sesuai tabel attribution (Tabel 3.8) maka persentase untuk attribution diperoleh sebesar 25\% untuk dampak tersebut.

Dan untuk dampak dari mendapatkan lapangan pekerjaan bagi alumni, diketahui bahwa alumni telah mendapakan pekerjaan setelah lulus menjadi mahasiswa STID Mohammad Natsir. Berdasarkan informasi ini maka atribution untuk dampak mendapatkan lapangan pekerjaan diperoleh sebesar 25\%.

\section{d. Drop-off}

Drop-off merupakan persentase seberapa besar pengurangan nilai dampak dari tahun ke-tahun. Dalam analisis SROI ini bahwa mahasiswa selalu mendapatkan program pendidikan kurikulum dan program-program wajib mahasiswa lainnya setiap tahunnya sehingga dampak yang dirasakan selalu ada. Dampak yang selalu muncul dan dirasakan oleh mahasisiwa ini menyebabkan tidak adanya pengurangan persentase nilai dari da mpak tersebut 
dari tahun ketahun sehingga berdasarkan temuan tersebut dapat disimpulkan bahwa drop-off diperoleh sebesar nol persen $(0 \%)$.

e. Menghitung dampak

Pada tahapan ini dilakukan perhitungan nilai dampak. Langkah pertama yang dilakukan adalah mengkalikan indikator dengan proksi keuangan. Kemudian dikurangi dengan persentase deadweight, attribution dan drop-off. Nilai total yang didapatkan adalah Rp. 74.196.960.613 (lampiran 17).

Grafik 4.1 Presentase Nilai Total Dari Setiap Dampak

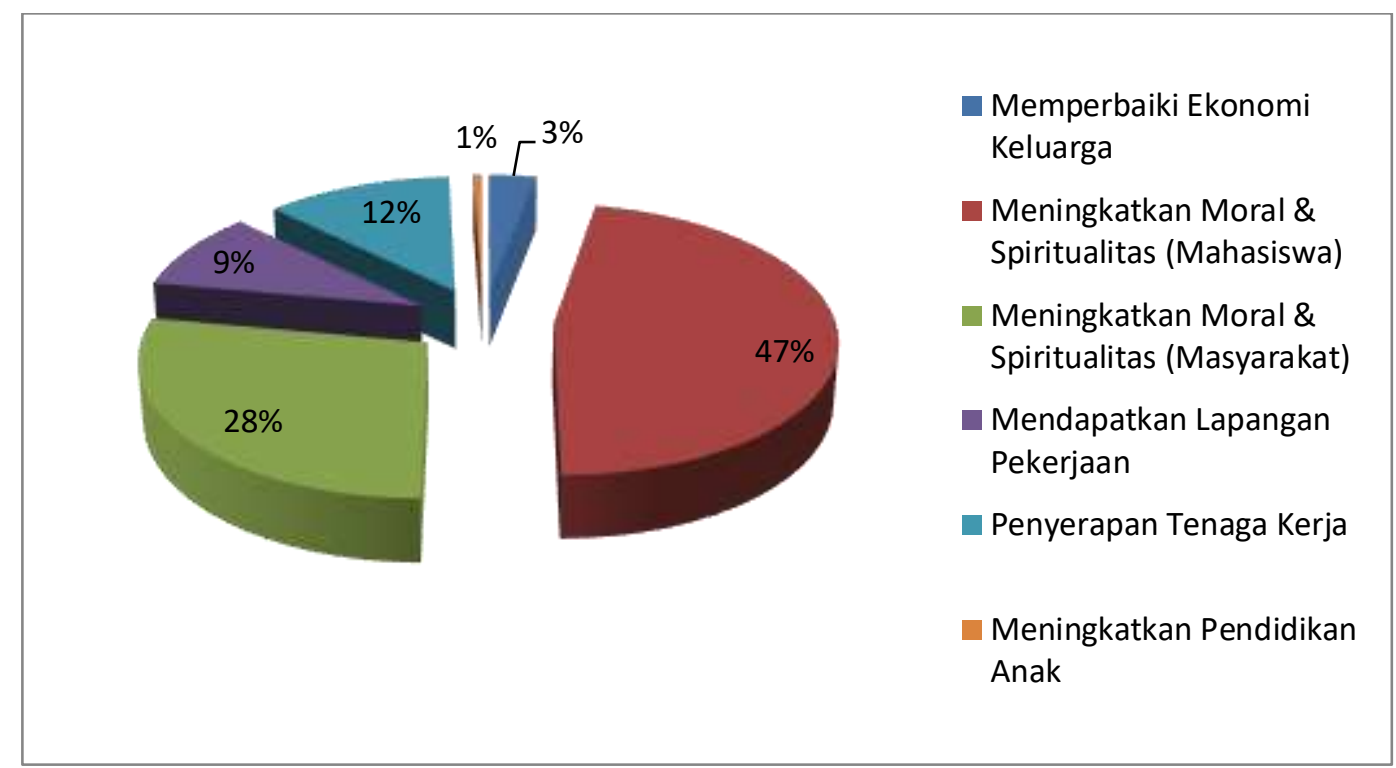

Dari gambar diatas dapat dilihat bahwa dampak dengan nilai terbesar adalah meningkatkan moral dan spiritual bagi mahasiswa dan masyarakat. Hal ini menunjukan bahwa program STID Mohammad Natsir dalam menyelenggarakan pendidikan pengkaderan Da'i dan pembinaan keagamaan kepada masyarakat pedalaman telah membawa manfaat yang sangat besar dalam peningkatan moral dan spiritual mahasiswa juga masyarakat. Sedangkan untuk dampak dengan nilai persentase terkecil yakni terdiri dari meningkatkan pendidikan anak. Hal ini menunjukan bahwa program STID Mohammad Natsir mampu mewujudkan harapannya dalam membangun masyarakat yang bermoral dan memiliki spiritualitas yang baik.

\subsubsection{Menghitung SROI}

Dampak atau dikenal dengan nilai dari perubahan dihitung dengan proksi keuangan dikalikan dengan kuantitas dari pengurangan dampak deadweight, attribution dan drop-off. Perhitungan SROI dilakukan menggunkan impact map spreadsheet. Total nilai dampak yang didapatkan dari hasil perhitungan dengan formula SROI adalah Rp. 17.798.000.000 (lampiran 14).

a. Memproyeksikan ke Masa Depan 
Nilai manfaat yang dihasilkan untuk setiap dampak diproyeksikan ke lima tahun kedepan. Dampak tersebut diasumsikan akan bertahan lebih dari satu tahun sehingga diperkirakan akan bertahan selama lima tahun. Dalam analisis SROI suatu dampak maksimal memiliki jangka waktu lima tahun. Analisis dilakukan menggunakan Net Present V alue (NPV).

b. Menghitung Net Present Value (NPV)

NPV dihitung dengan mengggunakan Discount Rate Bank Indonesia tahun 2018 yaitu 6,00\%. Analisis dilakukan menggunakan excel (lampiran 14).

c. Menghitung Rasio

Rasio SROI dihitung dengan membagi Net Present Value Of Benefit (NPV manfaat) dengan total input. Berikut perhitungan untuk mendapatkan rasio SROI :

$$
\text { SROI Ratio }=\frac{\text { Net Present Value of Benefit }}{\text { Value of Inputs }}=\frac{R p \cdot 17.798 .000 .000}{R p .3 .964 .799 .245}=28
$$

Hasil akhir perhitungan rasio SROI ini adalah 28:1 yang berarti bahwa untuk setiap Rp. 1,00 yang diinvestasikan, akan menghasilkan nilai sosial berupa manfaat yang dirasakan siswa dan karyawan/masyarakat sekitar sebesar Rp. 28,00.

Rasio SROI membandingkan benefit yang dihasilkan oleh suatu program dengan nilai input yang telah di berikan. Input biaya investasi sebesar Rp.3. 964.799 .245 telah menghasilkan manfaat sebesar Rp. 17. 798.000.000. Rasio SROI didapatkan dengan membagikan nilai manfaat yang dihasilkan dengan input biaya investasi yang diberikan. Rasio SROI yang dihasilkan dari program STID Mohammad Natsir ini adalah 28:1. Rasio SROI yang dihasilkan cukup besar. Hal ini mengindikasikan manfaat yang telah dihasilkan cukup berdampak kepada stakeholder STID Mohammad Natsir. Manfaat ini akan berlangsung selama 5 tahun. Dalam perhitungan SROI, tidak dianjurkan untuk membandingkan hasil rasio SROI yang ditemukan dari suatu organisasi dengan rasio SROI organisasi lain karena rasio SROI yang dihasilkan akan berbeda dari setiap organisasi.

\section{d. Analisis Sensitivitas}

Setelah menghitung rasio SROI, penting dilakukan penilaian untuk melihat sejauh mana hasil tersebut dapat berubah jika dilakukan perubahan terhadap beberapa asumsi yang dibuat pada tahap sebelumnya. Persyaratan standar untuk memeriksa perubahan tersebut adalah perkiraan deadweight, attribution dan drop-off, financial proxy, kuantitas dari dampak dan nilai dari input. Perhitungan SROI dilakukan dengan mudah di dalam lembar kerja excel. Semua nilai-nilai terhubung keperhitungan akhir yang secara otomatis menghitung rasio SROI. Hal ini menyebabkan bahwa nilai-nilai dapat diubah dengan mudah. Ketika dilakukan perubahan terhadap nilai-nilai yang ada maka akan terlihat bagaimana perubahan besaran rasio SROI tersebut. Ketika dilakukan perubahan terhadap nilai proyeksi keuangan dari dampak Meningkatkan Pendidikan anak sebesar 100\%, rasio SROI berubah menjadi 1:28,3. Berdasarkan percobaan tersebut dapat disimpulkan bahwa tidak terjadi perubahan yang terlalu signifikan ketika nilai proyeksi keuangan dampak dari meningkatkan pendidikan anak berkurang terhadap nilai rasio kembalian sosial yang dihasilkan oleh STID Mohammad Natsir.

e. Waktu Pengembalian Modal (Payback Period)

Langkah terakhir dari tahap lima adalah melakukan perhitungan untuk seberapa lama waktu yang dibutuhkan untuk membayar kembali biaya dari investasi awal. Payback period 
menjelaskan berapa lama waktu yang diperlukan untuk mengembalikan investasi. Payback period menunjukan waktu dalam bulan atau tahun untuk nilai dampak bisa melebihi nilai investasi. Perhitungan ini dilakukan untuk melihat seberapa lama investasi yang dikeluarkan oleh STID Mohammad Natsir dapat tertutupi kembali dengan nilai manfaat yang didapatkan. Dengan menghitung payback period STID Mohammad Natsir dapat menunjukan seberapa lama waktu yang dibutuhkannya untuk mengembalikan investasi meskipun tidak ada uang yang sebenarnya sudah pulih kembali. Langkah pertama yang dilakukan untuk menghitung payback period adalah membagi nilai dampak tahunan dengan 12 untuk mendapatkan nilai dampak bulanan. Berikut perhitungan payback period:

$$
\text { Payback Period }=\frac{\text { Investment }}{\text { Annual Impact } / 12}=\frac{R p \cdot 3 \cdot 864 \cdot 799 \cdot 245}{R p \cdot 17.798 \cdot 000 \cdot 000 / 12}=2,58
$$

Payback period untuk pengembalian sosial dari investasi yang dikeluarkan adalah 1 tahun 8 bulan. Hal ini berarti bahwa pengembalian modal untuk investasi program ini cukup cepat karena hanya memerlukan waktu 1 tahun 8 bulan.

\subsubsection{Pelaporan, Penggunaan dan Penerapan}

a. Pelaporan ke Stakeholder

Pelaporan hasil analisis kepada stakeholder sangat penting untuk dilakukan. Mengkomunikasikan hasil analisis berarti memastikan bahwa stakeholder baik itu pihak STID Mohammad Natsir ataupun mahasiswa mengetahui dan mengerti bagaimana manfaat yang mereka dapatkan dan seberapa besarnya. Bentuk pelaporannya berupa presentasi dan penyerahan hasil penelitian kepada Ketua Bidang Da'wah Dewan Da'wah Pusat dan Ketua Program LAZNAS Dewan Da'wah untuk nantinya menjadi bahan evaluasi bagi para stakeholder.

b. Menggunakan Hasil

Hasil analisis rasio SROI ini dapat digunakan sebagai alat komunikasi oleh stakeholder. Laporan ini dapat digunakan sebagai panduan seberapa besar manfaat sosial yang telah dihasilkan dari investasi bisnis yang dilakukan. Para stakeholder seperti pemerintah, donatur dan mitra STID Mohammad Natsir dapat mengetahui bahwa program yang dilaksanakan tidak hanya menghasilkan keuntungan finansial tetapi juga membawa manfaat sosial bagi sisiwa dan masyarakat sekitar tersebut.

c. Jaminan

Analisis SROI dalam penelitian ini dilakukan sesuai dengan prinsip-prinsip SROI dan tahapan-tahapan analisis didalam buku panduan penghitungan SROI "A guide to Social Return on Investment" (Nicholls et.al., 2012).

Tabel 4.8 Prinsip-Prinsip SROI

\begin{tabular}{|c|l|l|c|}
\hline No & \multicolumn{1}{|c|}{ Prinsip } & \multicolumn{1}{|c|}{ Uraian } & Keterangan \\
\hline 1 & $\begin{array}{l}\text { Memahami } \\
\text { perubahan }\end{array}$ & $\begin{array}{l}\text { Menyertakan teori perubahan dan } \\
\text { merumuskan perubahan }\end{array}$ & Terpenuhi \\
\hline
\end{tabular}




\begin{tabular}{|c|l|l|c|}
\hline 2 & $\begin{array}{l}\text { Mengikutsertakan } \\
\text { pemangku } \\
\text { kepentingan }\end{array}$ & $\begin{array}{l}\text { Menjadikan pemangku kepentingan } \\
\text { (stakeholder }) \text { sebagai responden } \\
\text { penelitian }\end{array}$ & Terpenuhi \\
\hline 3 & $\begin{array}{l}\text { Memberi nilai } \\
\text { pada sesuatu yang } \\
\text { penting }\end{array}$ & Terpenuhi \\
\hline 4 & $\begin{array}{l}\text { Hanya } \\
\text { mengikutsertakan } \\
\text { yang materiil }\end{array}$ & $\begin{array}{l}\text { Menyertakan perubahan yang } \\
\text { signifikan dan dampaknya dirasakan } \\
\text { oleh sebagian besar stakeholder }\end{array}$ & Terpenuhi \\
\hline 5 & $\begin{array}{l}\text { Tidak berlebihan } \\
\text { penyaringan atas dasar kehati-hatian }\end{array}$ & $\begin{array}{l}\text { Menetapkan dampak dengan sistem } \\
\text { Terpenuhi }\end{array}$ \\
\hline 7 & Tranparansi & $\begin{array}{l}\text { Menuliskan setiap alasan dan } \\
\text { keputusan yang diambil }\end{array}$ & Terpenuhi \\
\hline Verifikasi Hasil & $\begin{array}{l}\text { Melakukan verifikasi hasil dengan } \\
\text { pemangku kepentingan }\end{array}$ & Terpenuhi \\
\hline
\end{tabular}

Tabel 4.9 Tahapan-Tahapan SROI

\begin{tabular}{|c|l|c|}
\hline No & \multicolumn{1}{|c|}{ Tahapan } & Keterangan \\
\hline 1 & $\begin{array}{l}\text { Menetapkan Ruang Lingkup dan } \\
\text { Mengidentifikasi Stakeholder }\end{array}$ & Terpenuhi \\
\hline 2 & Memetakan Dampak & Terpenuhi \\
\hline 3 & Membuktikan Adanya Dampak & Terpenuhi \\
\hline 4 & Menetapkan Dampak & Terpenuhi \\
\hline 5 & Menghitung SROI & Terpenuhi \\
\hline 6 & Pelaporan, Penggunaan dan Penerapan & Terpenuhi \\
\hline
\end{tabular}

\section{KESIMPULAN}

Hasil akhir dari penelitian didapatkan rasio SROI sebesar 28:1 yang artinya setiap Rp.1,yang dinvestasikan oleh STID Mohammad Natsir maka akan menciptakan Rp.28,- manfaat sebagai dampak sosial atas investasi program tersebut. Dari program yang diselenggarakan telah menimbulkan enam dampak sosial yaitu: memperbaiki ekonomi keluarga, meningkatkan moral dan spiritual mahasiswa, meningkatkan moral dan spiritual masyarakat pedalaman, mendapatkan lapangan pekerjaan, penyerapan tenaga kerja dan meningkatkan pendidikan anak. Dari total dampak yang terjadi, 47\% terserap oleh dampak meningkatkan moral dan spiritual untuk mahasiwa, 28\% meningkatkan moral dan spiritual masyarakat pedalaman, 9\% mendapatkan lapangan pekerjaan, 3\% memperbaiki ekonomi keluarga, 12\% penyerapan tenaga kerja dan 1\% meningkatkan pendidikan anak. Hal ini menunjukkan bahwa STID Mohammad Natsir berhasil mewujudkan visi-misi dan tujuan dibuatnya program 
pendidikan pengkaderan Da'i yang dapat menciptakan dampak sosial yang membawa manfaat bagi mahasiswa dan masyarakat sekitar serta dapat memberi solusi dalam mencegah dan mengatasi terjadinya pertumbuhan pemurtadan di daerah pedalaman. Rasio ini masih memiliki kesempatan untuk ditingkatkan.

\section{DAFTAR PUSTAKA}

Academia.edu. (n.d.). Wakaf. Wakaf. https://www.academia.edu/6476278/Makalah_Wakaf

Agama, K., \& Haji, D. P. Z. dan W. dan D. J. B. M. I. dan P. (2013). Paradigma Baru Wakaf di Indonesia. simbi.kemenag.go.id

Assa'diyah, H., \& Pramono, S. (2019). Kenapa Muzakki Percaya Kepada Lembaga Amil Zakat? Jurnal Akuntansi Dan Keuangan Islam, 7(1), 81-100. https://doi.org/10.35836/jakis.v7i1.68

Badan Amil Zakat Nasional. (2017). Outlook Zakat Indonesia 2017.

Hepi Andi Batoni. (2013). kiat Islam Mengatasi kemiskinan. In Syaiful Anwar (Ed.), Beginilah Rasulullah Bebisnis (Cet. Kedua, p. 81). Pustaka al-Bustan.

IDEAS, D. D. (n.d.). Transformasi Zakat Nasional. https://ideas.or.id/2019/07/11/transformasi-zakat-nasional/

Natsir, S. M. (2019). Company Profile STID Mohammad Natsir. https//stidnatsir.ac.id

Nicholls, J., Lawlor, E., Neitzer, E., \& Goodspeed, T. (2012). A Guide to Social Return on Invesment. January. https://www.researchgate.net/publication/328754594_Social_Return_on_Investme nt_SROI_a_review_of_the_technique

The SROI. (2012). Social Return on Investment. Social Ventures Australia Consulting. https://socialventures.com.au/assets/SROI-Lessons-learned-in-Australia.pdf

Unggul Purwohedi. (2016). Social Return on Investment (SROI).

Yusanto, M. I., \& Yunus, M. A. (2011). Sistem Ekonomi Islam. In Arief B. Iskandar (Ed.), Pengantar Ekonomi Islam (p. 70). Al-Azhar Press 2011.

Wawancara-wawancara

Website:stidnatsir.ac.id

\section{PEDOMAN TRANSLITERASI}

Transliterasi Arab-Latin digunakan dalam jurnal Ilmu Dakwah Academic Journal for Homiletic Studies berdasarkan model Library of Congress, sebagai berikut:

$\mathrm{B}=\mathrm{c} \mathrm{dh}=\mathrm{j}$
$\mathrm{T}=\mathrm{t}=\mathrm{t}$




\begin{tabular}{|c|c|c|c|c|c|c|c|c|c|c|}
\hline Th & $=$ & $ث$ & $z$ & $=$ & j & ' & $=$ & $\varepsilon$ & $\mathrm{n}$ & $=$ \\
\hline $\mathrm{J}$ & $=$ & ج & $\mathrm{s}$ & $=$ & س & Gh & $=$ & $\dot{\varepsilon}$ & $\mathrm{w}$ & $=$ \\
\hline ḥ & $=$ & $\tau$ & $\mathrm{sh}$ & $=$ & ش & $\mathrm{F}$ & $=$ & ف & $\mathrm{h}$ & $=$ \\
\hline $\mathrm{Kh}$ & $=$ & $\dot{\tau}$ & s. & $=$ & ص & Q & $=$ & ق & ' & $=$ \\
\hline $\mathrm{D}$ & $=$ & د د & d & $=$ & ض & $\mathrm{K}$ & $=$ & ك5 & $\mathrm{y}$ & $=$ \\
\hline
\end{tabular}

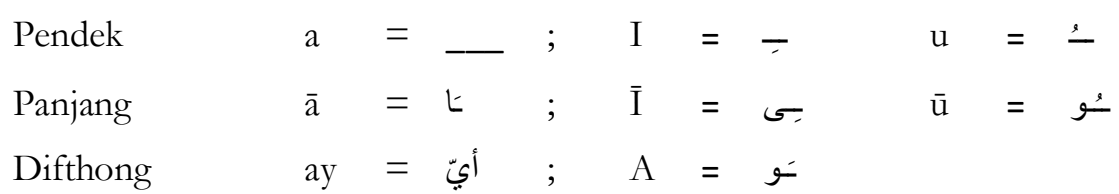

1. Kata berakhiran ta marbüthah (¿-) ditransliterasi tanpa menggunakan "h"; jika huruf berada di depan ta marbüthah ditransliterasi menjadi " $\mathrm{t}$ ".

2. Huruf alif-läm (ال) ditransliterasi menjadi al-; jika berada setelah preposisi maka hurufalif-làm ditransliterasi menjadi $l$ -

3. Ayat Qur'anditransliterasi sesuai dengan pengucapan. Contoh:

a. Bahasa Arab umum:
أهلية
سورةالبقرة
$=$ Abliyyah atauabliyya
هلالسنةو الجماعة
$=$ Sürat al-Baqarah
b. Ayat Qur'an:
= Abl as-sunnah wa'l-jamāáah
يأيهاالناس
$=$ Yã ayyuha $n$-nās

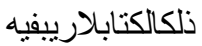
= Dhälikea 'l-kitābu lāraiba fìb 